\title{
China's place in a world in crisis
}

\section{Ross Garnaut}

The world and China's place in it have been transformed over the past year. The pressures for change have come from the most severe global financial crisis ever, and from what so far is the largest decline in output in a comparably short period in the history of the world economy.

China and its economic prospects have also changed, but not so much as China's place in a changing world. After a challenging year, China is confirmed on a course of continuing strong growth. There are still questions about longer-term sustainability, but there is now considerable cause for confidence that there will be positive answers. The global financial crisis has accelerated China's emergence as a great power, in advance of China or its global partners thinking and working through the consequences for managing the implications for the governance of world affairs.

These are the themes of this year's China Update.

The global China boom was at its height when the China Update's annual assessment was released a year ago (Song and Woo 2008). World resources and food prices were at record levels. Developing-country growth for 2007 was the strongest ever; even though things fell apart from September, growth for the year was more than 13 per cent for China, more than 9 per cent for India, more than 6 per cent for Africa and more than 8 per cent for all developing countries.

In 2009, economic growth is somewhat subdued but still strong in China and the large, successful developing countries. The economic outlook is now deeply problematic in the industrialised and poor developing countries.

The financial crisis of 2008 can now be traced back to weaknesses in the US financial system that began to be revealed from 2006. The crisis came in September 2008 with the collapse of several Wall Street investment banks. There was an immediate breakdown of the system 
of international financial intermediation, which had been smoothly transferring China's unprecedented surpluses to cover the unprecedented current payments deficits of the United States and Australia in particular (Garnaut forthcoming).

The financial crisis precipitated a global recession. In China, the recessionary pressures from the international economy reinforced the effects of an earlier tightening of monetary policy. This tightening had been designed to bring to an end level of inflation that had been worrying the authorities for more than a year. The restrictive monetary policy had pricked the bubble in the Shanghai and Shenzhen stock exchanges and caused a pause in the real estate boom in a number of major cities. The sudden drying up of orders from importers of Chinese goods in the industrialised countries caused retrenchment in the export factories and the abandonment of expansion plans in export-oriented enterprises. Tens of millions of urban workers returned to the farms, villages and townships of rural China.

Suddenly some of the long-term questions about the sustainability of China's early twenty-first-century growth strategy demanded immediate answers. Could China replace export-oriented growth with similarly strong growth focused on opportunities in the domestic market? Could China expand expenditure enough and quickly enough if developments in the international economy prevented the accommodation of China's huge and growing external surpluses?

Other long-term issues of the sustainability of China's early twentyfirst-century growth strategy remained to be answered. Was it possible for the world to manage the huge expansion of supply and delivery capacity for natural resources to fuel, feed and fabricate the demands of Chinese economic growth, at costs and prices that would be consistent with continuing growth in living standards in the whole world? Would China and the world find ways of breaking the nexus between economic output and emissions of the greenhouse gases that were rapidly increasing the risks of dangerous climate change?

Between last year's and this year's updates came the thirtieth anniversary of the commencement of reform - the anniversary of the time when Deng Xiaoping took control of the Central Committee of the Chinese Communist Party in December 1978 and moved decisively to implement policies of market-oriented reform and opening to the outside world. Each of the decennial anniversaries had coincided with crises for reform - the three 
substantial crises of the reform period. In late 1988, high inflation and disagreements within the leadership on how to handle it were setting the scene for the tragic developments of June 1989 and the only substantial challenge to reform. In late 1998, China had embarked on but did not yet know the fate of its risky policy response to the East Asian financial crisis: the maintenance of a fixed exchange rate against the US dollar and huge Keynesian fiscal expansion at a time when exports had stagnated and foreign exchange reserves were in rapid decline. Now, China has embarked on another huge fiscal and monetary expansion, this time in response to a global rather than a regional financial crisis and recession (Garnaut 2009).

Soon after the breaking of the global crisis, China embarked on an even larger expansion than in the late 1990s. It was the largest fiscal expansion of any country in response to the crisis of 2008. There was an even larger monetary expansion. The strongly restrictive instructions to the state banks were reversed in the final months of 2008 and replaced with instructions to expand lending.

There was much less risk in the expansionist strategy this time than during the East Asian financial crisis. China's extraordinarily large foreign exchange reserves meant that a flank that had been vulnerable in the late 1990s was now thoroughly covered. And the success of Keynesian policies through the East Asian financial crisis increased confidence in expansionary policies in the global recession.

It was clear by January that the immense and timely fiscal and monetary expansion was having a large effect. Chinese growth through 2009, from the December quarter of 2008 to the December quarter of 2009, is now likely to be comparable with annual growth in the years leading into the crisis. Chinese exports remain weak and the impetus to growth is coming from expansion of domestic demand. This is stabilising net exports, and as 2009 proceeds will make the external accounts a negative factor on Chinese growth. China will be a helpful stabilising factor in the global economy. Already the strong recovery of Chinese import demand has taken global energy and minerals prices off their late-2008 lows, to points halfway between the averages in real terms of the late twentieth century and the heights of the boom.

China's strong growth in the early twenty-first century before the global crisis was raising four large questions about its sustainability. 
First, there were questions about the extent to which it depended on growth of exports and a rising surplus in foreign trade. The strong growth in exports and huge and increasing trade surpluses were placing large structural pressures on its trading partners. At a time of weakness in the global trading system, this was threatening protectionist reactions. The payments surpluses were the other side of the coin of payments deficits in and transfers of capital to a few deficit countries - first of all the United States. This was convenient to the United States and other deficit countries, which were able to avoid hard choices of their own involving reduction of expenditure through the cutting of public expenditure, including on defence, the increasing of taxation and the raising of interest rates. Some analysts saw it as postponing and therefore exacerbating major adjustments that had to happen sometime and would be the more painful and costly for delay.

Second, there were questions about the extent to which growth on an unprecedented scale was placing pressure on local, national, regional and global environmental amenity. Increasingly, developments in China were seen as being of central importance to the emerging risks of dangerous climate change. Here the external costs of Chinese growth were carried by the global community and any solution to the global problem would need to involve all substantial economies including China (Garnaut 2008).

Third, the established patterns of growth in the early twenty-first century were associated with wide and increasing dispersion in the distribution of incomes. Inequality had fallen in the early years of reform with its concentration on agricultural and other rural development. By the early twenty-first century, the high earnings and ease of financing of projects in state-owned enterprises for capital-intensive projects were the first of several sources of bias concentrating incomes growth in the hands of relatively well off people in the cities, and especially in the wealthy coastal cities. The feeling among many ordinary people that they were not receiving an equitable share of the rich fruits of rapid economic growth was the source of social tension manifested, for example, in many protests against decisions of officials.

Fourth, there were questions about the effects of rapidly rising expenditure in China on global markets for food, minerals and energy resources. Chinese demand was a major influence on unprecedentedly high food, metals and energy prices in the time leading up to global recession. Would continued strong growth in China as it became a larger 
economy raise the prices of these commodities so high that they might not be compatible with continued growth in incomes and living standards on a global scale? The satisfactory resolution of the food and resource supply issues would require smoothly functioning goods, capital, transport and enterprise markets.

Could these sources of risk to continued strong economic growth be corrected without risking growth itself?

These four questions about the sustainability of growth were closely interrelated. The trade surplus was the other side of the coin to prodigious and rapidly growing savings rates - far higher than China's extraordinarily high investment rates. Inequality of earnings contributed to exceptionally high savings rates, since those who were well off saved a higher proportion of their incomes than the poor. The high profits and high incomes in the stateowned enterprises were two important elements in the growing inequality of incomes. The retention of a high proportion of these firms' earnings for investment in heavy industry and infrastructure perpetuated and exacerbated the inequality of incomes and contributed to disproportionate pressure on the environment and demand for minerals and energy resources.

There had been much discussion before the global crisis of changes in strategy that would reduce pressures arising in each of these four areas. President, Hu Jintao, and Premier, Wen Jiabao, in successive statements had emphasised the importance of expanding expenditure and promoting development in rural areas and shifting the balance in resource allocation towards such human services as health and education. Improved environmental amenity was to be an important focus of increased expenditure and there was increasing official focus on China's role as a victim and source of and contributor to solutions to the global warming problem.

The adjustments would be associated with less intensive use of resources.

Only small progress had been made in giving effect to these official statements of good intentions before the international crisis. The appreciation of the Chinese against US currencies by about 20 per cent in three years or so from July 2005 would, when accompanied by expansion of public expenditure in rural areas, contribute to easing external balance, reduction in inequality and pressure on the environment and natural resources. 
There was a sense in which these four sets of questions about sustainability of established patterns of rapid growth in China could be partially self-correcting. By the mid-1990s and more strongly from the early twenty-first century, labour was becoming scarce enough in many parts of China for real wages to rise rapidly. This contributed to rising consumption and potentially to reduced competitiveness of exports and import-competing production of labour-intensive goods and lower shares of investment in heavy industry with their impacts on resources and the environment.

These were possibilities that had not been realised before the crisis. Productivity, output and incomes rose even more rapidly than real wages and consumption. Rates of return on investment continued to be high and to rise. It would take even higher rates of growth in output and incomes and even higher rates of growth in real wages for these market processes to make inroads into China's surplus savings and income inequalities. Faster growth in itself, even with the structural change associated with rapid increases in real wages, would increase pressure on resources and the environment in the absence of other corrective measures.

Now the crisis makes large and immediate structural change a condition of continued rapid economic growth. The rest of the world is rapidly reducing its deficit of savings relative to investment. This is part of the cautious response of households and businesses, and is in any case forced by the collapse of the banks that once transferred funds smoothly from the surplus to the deficit countries.

China cannot continue to grow with rapid increases in its net exports, payments surplus and foreign exchange reserves.

It can, however, continue to grow rapidly. This requires the rapid expansion of domestic demand. There are limits to the rate of increase in private consumption, so much of the expansion, especially in the early stages, must take the form of public expenditure-investment and consumption - and of private investment. The investment share of output and expenditure is likely to have to rise for a while from current levels. If spent well - and there are still abundant opportunities for productive and highly profitable investment in China - this would require even higher rates of growth of output than in the Chinese experience before the crisis. Higher growth, in turn, would bring forward pressures for real wages to rise and for consequential structural change. 
This is the world that China has entered in the aftermath of the global crisis. It is a world of development that will be associated with major reductions in China's trade and payments surpluses. Over time, it is likely to be associated with moderation of income inequalities - although not necessarily in the near term.

Early correction of growing inequalities, as well as reduction of the pressure on resources and the environment from rapid economic growth, would require the successful implementation of complementary policies. Reduction in income equalities would require much of the expansion of public expenditure to be focused on the supply of education, health services and transport and communications infrastructure on lower income and especially rural communities. For China to reconcile continued rapid economic growth with playing its proportionate part in a global effort to mitigate human-induced global warming would require deliberate measures to tax or to regulate emissions, and to accelerate commercialisation of new, low-emissions technologies. Success in breaking the nexus between economic growth and greenhouse gas emissions would moderate growth in demand for non-renewable resources.

The early Chinese stimulus packages contained elements of increased expenditure directed to income distribution and environmental issues. This component has tended to expand in successive packages.

The sustained rapid growth of China and other large developing countries in the early twenty-first century has been changing the international economic and strategic balance. The tectonic plates of global economic weight and therefore eventually strategic influence have been shifting towards a quadripolar world in which four great powers will need to work cooperatively to achieve major international objectives: the United States, the European Union, China and India. Effective international action on most issues will require cooperation between the four, and leadership from China and the United States.

This is a world so changed that it will take time to develop the ideas and the institutions through which international cooperation can be effective.

The global crisis has not changed the directions of movement of the tectonic plates. It has accelerated the movement, by substantially slowing the growth of the major industrialised countries while affecting much less the major developing countries. This reduces further the time within which new approaches to and institutions for management of the new 
international order must be developed. Less time means greater chance of damaging mistakes.

These are the issues covered by the contributions to this book. How have China's growth prospects been affected by the global crisis? How will the crisis and China's response to it affect the prospects for progress on the great internal issues in China's development? How will the crisis and the international community's response to it affect the rapidly emerging new international order, in which China and other major developing countries have much larger roles?

The next three chapters discuss some ways in which the crisis has affected ideas in China and elsewhere about international institutions that are necessary to make the new world work.

Woo (Chapter 2) notes that the crisis completes the discrediting of the advice from the Washington-based global financial institutions on the policy response to the East Asian financial crisis a decade ago. This validates the search for alternative regional institutions for financial cooperation. Woo favours a plurality of institutions providing international public goods, including one or more with East Asian regional roots. His practical suggestion is modest: support for an Asian finance facility, in which the United States would be invited to participate, as a defence against financial contagion. The strong reserves position of East Asian economies places them in a good position for effective cooperation in this area.

Several chapters discuss the haunting question: did developments in China contribute to the global financial crisis? Chen (Chapter 3) takes preemptive action by identifying flawed economic and financial analysis of financial markets at the centre of the problem. He notes that some US analysts have seen strong causal roles either for low Chinese savings, high external payments surpluses and a low exchange rate, or for the complementary imbalances between China and the United States. He sees the antidote to future crises mainly in financial reform in industrialised countries and expresses concern that currently proposed remedies for the global recession will be too weak for the task.

Corden (Chapter 6) considers the matter carefully and concludes that the Chinese surpluses might have made some small contribution to the crisis. Flaws in developed financial markets were more important. 
Ma and Zhou (Chapter 4), Corden (Chapter 6) and Wang and Fan (Chapter 8) all discuss the puzzling and important reality that lies behind the Chinese payments surpluses: the exceptionally high Chinese savings rates. Corden presents the data simply and shows that China's exceptional trade and current account surpluses are recent phenomena-mostly since 2005. He notes that Chinese household savings are high (15 per cent of GDP despite an unusually low household income share), but these are of modest dimension compared with enterprise savings (28 per cent of GDP). Ma notes as well the high contribution of government surpluses (reductions of debt), which have risen strongly since 2002. Wang and Fan explore the links between high and increasing inequality in the distribution of income and the savings rate.

Ma and Zhou carefully analyse the factors contributing to rising savings shares in recent years and possible future tendencies. The age structure of the Chinese population has been highly and increasingly favourable for high savings in recent years. They conclude that it is unlikely that the external accounts will turn around into deficits, but the surpluses will not continue to grow and will probably decline. Xiao, Yang and Janus (Chapter 9) analyse the determinants of profitability of state-owned enterprises and so illuminate one of the sources of high and increasing inequality and also high savings rates in China. They explain proposals to reduce the privileged positions and improve the performance of firms operating in the sector.

Several chapters note that whether or not the dependence of growth in recent years on increasing exports and net exports was favourable for China, it will not be possible after the global crisis. The industrialised countries will not be prepared or able to fund the deficits that would need to be the counterparts of Chinese surpluses.

Is an alternative pattern of development built around expanding domestic demand feasible? The general view is that it is necessary, feasible and, if implemented well, desirable on other grounds as well.

Wang and Fan remind us of the long history of analysis of deficiencies in demand, from Marx through to Keynes in theory and Roosevelt in practice. They describe a simple model to illustrate how increased investment alone will not fill the gap on a long-term basis. They note, following Keynes, the essential role of government expenditure in filling the demand gap from time to time. They might have added that increased investment can and must take a major part of the load for a while. 
Even if China were successful in shifting the balance between savings and investment by increasing the consumption share of expenditure, it would still have such large external assets that their disposition would be of major importance for China and the rest of the world. Ma and Zhou note that China has moved quickly from being a substantial net debtor in 1999 (net foreign liabilities of 9 per cent of GDP) to being a large net creditor (33 per cent of GDP in 2007). As Corden observes, this was an outcome of other objectives and policies and policy constraints, and not the result of deliberate policy.

Ma and Zhou note the highly unbalanced and unusual composition of China's external assets and liabilities. Its assets are concentrated in fixed-interest securities, especially in the United States. Its liabilities are concentrated in direct foreign investment in China. They contrast the low returns on this asset portfolio with outcomes for Hong Kong, which holds a much higher proportion of its external assets in higher yielding securities including equities. It is inevitable and unexceptionable for China to seek to rebalance its foreign financial assets in the period ahead.

It is natural and unexceptionable in principle for China to hold a much higher proportion of its foreign assets in equities. Drysdale and Findlay (Chapter 16) show that this is easier said than done by reference to the nationalist reaction in Australia to increased Chinese interest in direct investment in the resources sector. Australian policy has found itself in a conceptual tangle. The substantive Australian national interest can be secured through long-established policy on foreign direct investment. Chen makes the interesting suggestion that China would face less resistance to direct investment abroad, and might make better investments, if it diversified the holding of its assets through endowment of a range of public institutions.

Chen (Chapter 15) reminds us that direct foreign investment into and out of China is keeping this dimension of globalisation alive when the financial crisis has closed down most direct foreign investment into industrialised countries. Direct foreign investment into China fell somewhat in the last quarter of 2008 as the financial crisis struck its heaviest blow, but picked up much of the lost ground in the first quarter of 2009. The moderate decline in investment into China has been mainly in real estate. There was a large decline in direct foreign investment in the world as a whole and into and out of industrialised countries in 2008, but Chinese investment abroad doubled. This was an important support for continued growth in 
developing countries in particular. In Australia, it allowed production to continue at some resources projects, and development to proceed at others, when this would not otherwise have been possible after the crisis.

Huang, Peng and Shen (Chapter 7) assess the economic outlook after the crisis and the expansionary policy and conclude that China is back on a path of reasonably strong growth. In an analogue of the discussion of direct foreign investment, they note that after falling initially, Chinese imports are steadying and are contributing a stabilising element to global trade. Chinese import demand has lifted prices for minerals and energy commodities from the trough into which they retreated in the immediate aftermath of the crisis.

Martin (Chapter 14) reminds us of one area in which the global trading system moved forward in 2009: with the European Union and the United States finally applying Uruguay Round liberalisation of textile and clothing trade to China, the world is operating without systemic quantitative restrictions on trade in these products for the first time in half a century. Chinese shares of the previously restricted markets have increased sharply, but this has been partially matched by a decline in Chinese shares of other markets, which had been open from earlier times.

Three chapters take us deep into analysis of the Chinese labour market. Athukorala, Fukao and Yuan (Chapter 10) apply the theories of development in labour-surplus economies to the experience of China. The rising profit shares of value added are consistent with the theory and with Hong Kong's experience at an earlier stage of its development. The demographic structure of China has supported exceptionally rapid growth of the labour force, well in excess of growth in the population, over the later reform period. Nevertheless, Chinese real wages have been growing rapidly since the mid-1990s, and especially since 2002. Real wage growth has been strongest in the coastal areas and in state-owned enterprises, but has been considerable in all geographic regions and classes of ownership. Labour productivity growth has been so strong that the labour shares of enterprise value added and unit labour costs have continued to fall despite rapid increases in real wages.

Cai, Wang and Qu (Chapter 11) introduce new dimensions into labour market analysis by referring to regional differences in patterns of internal migration and capital flows. Labour-intensive production for export in coastal areas was running into competitiveness issues before the global financial crisis with the rapid growth in real wages. The crisis provides an 
opportunity for productive structural change. Productivity growth has generally run ahead of rapidly rising real wages, but requires continuing change in the structure of production. China is not a single, homogeneous economy in relation to all the factors affecting comparative advantage in production. International trade analysis needs to take account of changing comparative advantage among regions of China as well as among national economies.

Kong, Meng and Zhang (Chapter 12) focus on the impact of the financial crisis. They note that it is one factor applying pressure to employment through 2009, alongside new labour laws that increase the cost of employing labour and the restrictive monetary policy before the crisis. They note the huge numbers of people who returned to their home areas from urban jobs as the crisis hit late in 2008. They present official data on the number of people who had not recovered employment some time after the Spring Festival in 2009. The data from their own Australian National University-Beijing Normal University survey suggested a higher proportion of people who had not returned to employment - in the range of 13-19 per cent of the total urban labour force from rural areas before the crisis.

McKay and Song (Chapter 13) place Chinese economic development in the reform period on a larger canvas. They compare resource use, urbanisation and industrialisation with industrialised countries at corresponding stages of development, focusing especially on the United States, Japan and South Korea. China is unexceptionable in an East Asian context. However, the high intensity of energy use has implications for emissions of greenhouse gases that were not known to be important for the countries that experienced industrialisation earlier in history.

This sets the stage for three papers on environmental management in Chinese development, with a special focus on the global warming issue.

Zhang and his colleagues in the Development Research Centre (Chapter 17) make an analytically outstanding contribution to the Chinese and international discussion of mitigation responses to global warming. They are uniquely placed to be influential, so that their contribution is of special importance. Their chapter argues that China and other developing countries should be prepared to accept binding caps on emissions, so long as the caps are set fairly, by carefully defined and appropriate criteria. They recognise the problem of carbon leakage, with emissions-intensive industries moving to countries with weaker policies, and see this as a 
reason for seeking caps in all countries. Like carbon leakage, the problems commonly identified in relation to carbon embedded in industrial products are best managed through all countries accepting a cap. Once entitlements have been defined, trade in entitlements will reduce the costs of reducing emissions. Once entitlements are defined for each country, all countries have powerful national interests in reducing emissions. The authors endorse the per capita basis for allocating entitlements, but argue for applying that in a very different way to Garnaut (2008): they see per capita entitlements as covering historical as well as future emissions, whereas the Garnaut Review looked forward to convergence on equal per capita entitlements at some time in the future. Zhang and colleagues accept that there was an alternative approach to dealing with the historical legacy proposed in the Garnaut Review, built around the industrialised countries taking special financial responsibility for research, development and commercialisation of low-emissions technologies, and for adaptation to unavoidable climate change in developing countries. If there is to be an effective international agreement on greenhouse gas mitigation that adds up to a global solution, we must have before us for discussion concrete proposals that can add up to a solution. No single proposal - neither that of the Garnaut Review nor that of Zhang and colleagues - will immediately receive the support of all relevant parties. By putting concrete proposals for discussion, however, we can come to understand what is important to various parties to the discussion and work towards a productive outcome.

Howes (Chapter 18) takes a look at China's own domestic commitments to reductions of emissions below business as usual and comments that these would meet foreign expectations of China in an early phase of global mitigation. This provides an opportunity for China to play a major role in the search for a global agreement by committing itself firmly in international fora to outcomes that are already covered by domestic policy. Howes notes the welcome increase in Chinese willingness to consider international commitments to contain the growth in emissions within the right context - embodied, for example, in the Zhang contribution to this book, and in two other major recent Chinese papers.

Xue (Chapter 19) discusses the general tendency for environmental concerns to rise in importance with economic development. This is elevating environmental issues in the Chinese policy agenda-rather earlier and more strongly than one would expect at China's income level. In the special case of global warming, this is a necessary condition for China's effective participation in a global mitigation effort. We could add 
that the sufficient condition is the presence of an international agreement to which China is a party.

White (Chapter 5) explores the implications of continued rapid economic growth in China and of the likelihood that China's relative economic performance will be enhanced rather than diminished by the global crisis. Strategic weight is closely related to economic size, although there has been some stickiness in the bringing to account of Chinese strong economic growth of the past three decades. This stickiness is likely to be a temporary phenomenon, followed by a catching up. The trigger for the catching up might be the realisation that the time when the economic size of China exceeds that of the United States is not far in the future. A politically stable Asia Pacific region will require China and the United States to accept that its exercise of power will need to be qualified by recognition of the interests and perspectives of the other. This will not be easy for either, and especially for the United States after its long period of strategic superiority in Asia.

\section{References}

Garnaut, R., 2008, The Garnaut Climate Change Review, Cambridge University Press, Melbourne.

Garnaut, R., 2009, 'Thirty Years of Chinese Reform and Economic Growth' in J. Lin, Y. Yao and H. Wu (eds), Reform and Development in China: What can China Offer the Developing World, Routledge Publishing.

Garnaut, R. and Llewellyn-Smith, D. forthcoming 2009, The Great Crash of 2008, Melbourne University Press.

Song, L. and Woo, W. T. (eds), 2008, China's Dilemma: Economic Growth, the Environment and Climate Change, Asia Pacific Press, Canberra, The Brookings Institution Press, Washington, DC, and Social Sciences Academic Press, Beijing. 